9. Сирил Норткот Паркинсон. Афоризмы URL: https://time365.info/aforizmi/temi/chinovnik (дата доступа 04.03.2020)

\title{
PROBLEMS OF BAILIFF'S RESPONSIBILITY IN THE CONTEXT OF THE FORMATION OF THE DIGITAL ECONOMY IN RUSSIA
}

\author{
(c) 2020 Ageeva Galina Evgenevna \\ Candidate of Law, Associate Professor \\ (c) 2020 Kolga Olga Viktorovna \\ Student \\ Samara State University of Economics \\ E-mail: dgims1@mail.ru, galinaageevva@mail.ru
}

Keywords: responsibility, bailiffs, digital economy, enforcement proceedings.

The article is devoted to understanding the nature of the Institute of responsibility, the study of legal regulation of the FSSP, as well as the analysis of problems related to the Institute of responsibility of bailiffs in modern society.

УДК 338

Код РИНЦ 10.00.00

\section{ОСНОВНЫЕ ПРОБЛЕМЫ РАЗВИТИЯ СУДЕБНОЙ СИСТЕМЫ РОССИЙСКОЙ ФЕДЕРАЦИИ}

\author{
(C) 2020 Агеева Галина Евгеньевна \\ кандидат юридических наук, доцент \\ (c) 2020 Котыхова Анастасия Александровна \\ студент
}

Самарский государственный экономический университет

E-mail: galinaageevva@mail.ru, kotyhova2011@mail.ru

Ключевые слова: судебная система, государственные институты власти, независимость судей, материально-техническая поддержка, доступность правосудия, защита прав и законных интересов граждан и организаций, статус судей.

Статья посвящена анализу основных проблем, возникающих при функционировании судебной системы Российской Федерации. Авторы рассматривают выявленные проблемы как комплексное, сложное и многообразное явление. В ходе исследования авторами предлагаются пути их решения, а также меры, которые могут повысить качество и доступность правосудия и устранить недоверие к судебной власти среди значительной части населения. 
С провозглашением в нашей стране принципа разделения властей на законодательную, исполнительную и судебную, особая значимость и роль стали принадлежать независимой судебной системе. Каждая из указанных ветвей власти осуществляет свои полномочия посредством юридических форм, и только деятельность судебных органов по отправлению правосудия облекается в особую процессуальную форму. Это связано с тем, что на суд возлагается не только функция по разрешению социальных конфрликтов, но он также призван к активному участию в механизме "сдержек и противовесов", а именно к осуществлению судебного контроля над другими ветвями власти, в особенности исполнительной 1 .

Поэтому можно с уверенностью сказать, что только конкретный институциональный статус судебной власти не может служить показателем ее эффективности. На это также влияет и наличие иных социальных институтов, и конечно, в первую очередь, государственных институтов (президент, парламент, правительство). И если брать во внимание независимый характер судебной власти, то сокращение ее реформы до изменения ее институционального облика, выраженное формальными нормами, является важным, но, в то же время, односторонним подходом. Для того чтобы исправить эту ситуацию необходимо учесть как общественный фактор, в котором действует институт, и его особенности, так и качество функционирования иных государственных институтов власти, а также их взаимную связь и влияние друг на друга.

Основы судебной системы, функционирующей в настоящий момент, были заложены в Концепции судебной реформы 1991 года². Затем организация судебной власти была закреплена в Конституции РФ и принятыми в соответствии с ней федеральными конституционными законами ${ }^{4}$. Структура российской судебной системы включает в себя суды общей юрисдикции и арбитражные суды. проблем.

На данный момент в российской судебной системе существует несколько основных

Первая проблема - это независимость судей. Для современного гражданского общества она обусловлена тем, что в случае, если судья не обладает полной независимостью, обеспечение государством подлинного правосудия невозможно и, следовательно, общество теряет доверие к судебным решениям 5 . В этом случае важно помнить о том, что судебный состав состоит лишь из квалифицированных, юридически компетентных и высоко моральных людей, честно и добросовестно выполняющих возложенные на них функции.

Низкий уровень материально-технической поддержки системы судов является следующей проблемой рассматриваемого явления. Названная проблема выражается в неудовлетворительном состоянии зданий суда, недостаточности специальных помещений для конвоя и подсудимых, а также в низкой доступности оргтехники. Для того чтобы повысить уважение и доверие к судебной власти со стороны населения, необходимо усовершенствовать материально-техническую базу судебных органов 4 .

Ужесточение условий для лиц, которые ходатайствуют о статусе судьи, является еще одной ступенью на пути к повышению эффективности судебной системы. Без подготовки и профессионального развития судей, невозможно осуществление правосудия на должном уровне. Потребность в постоянном совершенствовании навыков судебной власти продиктована частыми изменениями в законодательстве ${ }^{6}$. 
Следующей проблемой можно назвать организационные недостатки в деятельности судов. Названная проблема, в первую очередь, обусловлена сильной занятостью судей, что, несомненно, влияет на характер разбирательства. В этом случае, считаем, что "для повышения эфффективности рассмотрения и разрешения дел, судья должен быть освобожден от непроцедурных обязанностей, не носящих процессуального характера, таких как принятие исковых заявлений и других, делегировав эти полномочия своим помощникам"7.

Объединение Верховного и Высшего Арбитражного судов является инновацией судебной системы. Однако, указанная реформа более спорна и вызывает множество споров и критики, нежели одобрения, как со стороны ученых, так и со стороны юристов-практиков.

Доступность правосудия - это следующий важный вопрос. В настоящее время в судах действует система видеоконференцсвязи. Указанная технологическая составляющая играет весомую роль. Благодаря введению этой системы, проблема доступности правосудия в значительной степени решена. Еще в недалеком прошлом это казалось невозможным.

На основании вышесказанного, можно сделать вывод о том, что проблемы, которые возникают в процессе совершенствования судебной системы, имеют комплексный характер, являются сложным и многообразным явлением. Для их решения необходимо выработать соответствующие меры, которые помогут повысить качество и доступность правосудия, а также устранить то недоверие к судебной власти, которое имеет место быть среди значительной части населения.

Таким образом, актуальность проблем судебной системы обусловлена тем, что эта ветвь государственной власти призвана обеспечивать защиту прав и свобод человека и гражданина от любого правонарушения.

На основании вышесказанного, можно сделать вывод о том, что все проблемы, которые возникают в процессе функционирования судебной системы Российской Федерации, затронуть трудно. Тем не менее, постепенное решение проблем будет способствовать повышению эффективности судебной власти, а, следовательно, и успешному осуществлению защиты прав и законных интересов граждан и организаций.

1. Ярошенко Н.И. Место судебной власти в системе разделения властей в России // Вестник РУДН. 2010. № 3. С. 14.

2. Постановление ВС РСФСР от 24.10.1991 г. № 1801-1 "О Концепции судебной реформы В РСФСР" // Ведомости СНД и ВС РСФСР. 1991. № 44. Ст. 1435.

3. Конституция Российской Федерации: принята всенародным голосованием 12.12.1993 (ред. от 21.07.2014) // Собрание законодательства Российской Федерации. 2014. № 31. Ст. 4398.

4. Баранова А.С., Меркулова В.И. Основные проблемы развития российской судебной системы // Инновационная наука. 2018. № 4. С. 128.

5. Кондрашев А.А. Проблемы реализации принципа независимости судей в России: от теории к правоприменительной практике // Актуальные проблемы российского права. 2015. № 8 (57). С. 183.

6. Ефанова Е.А.Проблемы статуса судьи в Российской Федерации // Судебная власть и уголовный процесс. 2016. № 3. С. 120.

7. Древаль Л.Н. О некоторых проблемах районных судов // Вестник Московского университета МВД России. 2014. № 10. С. 274. 


\title{
MAIN PROBLEMS OF DEVELOPMENT OF THE JUDICIAL SYSTEM OF THE RUSSIAN FEDERATION
}

\author{
C) 2020 Ageeva Galina Evgenievna \\ Candidate of Law, Associate Professor \\ (C) 2020 Kotuhova Anastasia Alexandrovna \\ Student \\ Samara State University of Economics \\ E-mail: kotyhova2011@mail.ru, galinaageevva@mail.ru
}

Keywords: the judicial system, state institutions of power, independence of judges, material and technical support, access to justice, protection of the rights and legitimate interests of citizens and organizations, the status of judges.

The article analyzes the main problems that arise in the functioning of the judicial system of the Russian Federation. The authors consider the identified problems as a complex, complex and diverse phenomenon. In the course of the study, the authors suggest ways to solve them, as well as measures that can improve the quality and accessibility of justice and eliminate distrust of the judiciary among a significant part of the population.

УДК 342

Код РИНЦ 10.00 .00

КОНСТИТУЦИОННО-ПРАВОВОЙ СТАТУС ПРЕЗИДЕНТА РОССИЙСКОЙ ФЕДЕРАЦИИ

\author{
() 2020 Азарова Виктория Владимировна* \\ студент \\ (C) 2020 Гурбанова Гюльнар Мустафа кызы* \\ студент \\ Самарский государственный экономический университет \\ E-mail: v1kazarova1410@mail.ru, qulya01@mail.ru
}

Ключевые слова: Президент, Российская Федерация, государство, Конституция, глава государства, функции, полномочия, статус.

Отмечается, что Президент занимает особое место в государственной власти Российской Федерации. Глава государства - это гарант Конституции РФ, прав и свобод человека и гражданина, суверенитета страны и целостности ее территории. Поэтому правовой статус Президента должен быть особенно детально проработан, а граждане государства, на наш взгляд, должны быть хорошо осведомлены о его основных функциях и полномочиях.

*Научный руководитель - Цельникер Григорий Феликсович, кандидат юридических наук, доцент. 